Modern Asian Studies 41, 2 (2007) pp. 253-286. (C) 2007 Cambridge University Press doi:10.1017/S0026749X05002283 Printed in the United Kingdom

\title{
Who is a Brahmin in Singapore?
}

\author{
ASHVIN PARAMESWARAN* and RODNEY SEBASTIAN
}

\section{Curtin University of Technology}

\section{Introduction}

Brahmin identity and community-these are the essentials. Melody cannot be understood except by the notes and spaces that constitute it. So too with the group. To know it, we must understand individuals and their interactions. Failure to do this sacrifices accuracy for simplicity; realities get replaced with poor simulacra of themselves. Consider caste names; are they contested? A common assumption is that they are not.

However, Sundar reports that colonial censuses catalysed petitions for name changes amongst some castes (Sundar 2000: 115). Parry shows that in Kangra, castes perceived as Shudras by others see themselves as Kshatriyas or Brahmanas (Parry 1979: 110). Lynch describes how the self narratives of Brahmins from Mathura are disputed by other groups who view them as Non Brahmins (Lynch 1996: 98). In Nepal, one person was simultaneously designated a Jugi, Pore, Sanyasi, and Halhulu (these are caste names) by different sections of Newari society (Parish 1996: 1 14-15). In Bali, 'Ngakan become Dewa, Dewa become Anak Agung, Anak Agung become Cokorda' (these are caste names) (Howe 1996: 26). These examples show that many groups contest caste names. Isn't it likely, however, that caste names are also contested within each group?

If true, then these writers fail to go far enough. They surmount one false assumption-caste names are never contested-but leave another-group opinions are homogeneous, definite, and staticintact. When each group in the examples given is dissected, a myriad of opinions will probably emerge. In Kangra, some might see themselves as Shudras, not Kshatriyas or Brahmanas. In Mathura, some might feel they are Non Brahmins, not Brahmins. The person in Nepal may be

* Corresponding Author.

oo26-749X/o7/\$7.50+\$o.10 
ascribed more names. Does no one in Bali refuse to change castes? Is no one denied the right to do so? Of course, generalisations made on the basis of strong evidence are warranted. But taking for granted that in any group a single opinion exists, or a hegemonic one prevails, is wrong. None of the writers mentioned provides strong evidence to support their generalisations. None even states that such an assumption is being made.

This essay is a case study of Brahmin identity and community in Singapore that avoids these mistakes (though others are surely abundant). We do not assume that caste names are fixed. Neither do we neglect the impact of differing psychologies. Instead, we begin with the question, 'Who is a Brahmin in Singapore?', and answer this by constructing and verifying a cognitive model that explains how individuals ascribe, contest, and renegotiate Brahmin identity. Through this model, we show that in Singapore, a Brahmin is only a Brahmin, to some of the people, some of the time. A second question, 'Is there a Singaporean Brahmin community?', is then asked. In response, beliefs about this community are discussed. The discussion reveals that a Singaporean Brahmin community is imagined. It exists simply and only because a majority of individuals are convinced it does.

This study is significant because it demonstrates that diasporic caste identities-here delimited as comprising names and statuses-can be extremely fluid. Simultaneously, it shows how psychological analysis can form the basis for a sociological understanding of caste; how one need not be sacrificed for the other. Though this essay is neither a traditional ethnography nor a treatise on caste in the diaspora, it also functions as a valuable information resource, particularly because the only other work on Brahmins in Singapore was written in 1975 (Govindasamy 1975).

\section{Literature Review}

Caste identities are not monoliths; they are plastic, variable, and complex. Preventing this understanding are assumptions that any or all parts of these identities are always fixed. These assumptions arise from the tendency to circumscribe caste with fundamental, immutable properties. Illustrating such essentialisms are persistent parables (we use this term quite deliberately) in academia and popular culture. One is that caste is the principal constituent of Indian civilisation (Inden 1986: 402). Excellent deconstructions by Inden (Inden 1990: 
49-84) and Dirks (Dirks 2001: 5) demonstrate that this belief is a device invented and entrenched by colonials through mechanisms like the census (Cohn 1987). Dumont (1970) spearheads a second parable; that hierarchy defines caste. Searle-Chatterjee and Sharma refute this, pointing out that he confuses distinctiveness and typicality; he conflates differences between Western and Indian society (notions of purity and pollution) with what is central in the latter (SearleChatterjee and Sharma 1994: $5^{-6) \text {. }}$

Gould, whose book is entitled The Hindu Caste System, numbers among those who believe a third parable, that caste is only the province of Hindus (Gould 1987). Empirically this is untenable because caste exists amongst Indians of other religions such as Islam (Ahmad 1978), Christianity (Tharamangalam 1996), Buddhism (Mitra 1994: 56), Sikhism (Kaur 1986), and Judaism (Singh 1992: 178-214). Conceptually, the term Hindu is itself a complex and contested category. To define caste as varna, jati, or both-a fourth parable-is also problematic. Indologists derive varna from Sanskrit texts and refer to it as a fourfold functional system comprising Brahmanas (priest, teacher, counsellor), Kshatriyas (ruler, warrior, administrator), Vaishyas (agriculturalist, merchant), and Shudras (labourer, serf). Social scientists derive jati from fieldwork and refer to it as a kin based stratification system with properties like hierarchy, commensality, and endogamy. But there are many varna schemes (Fox 1969), thousands of distinct jatis with the same name, jatis that do not practise the properties mentioned, and jatis that either cannot be located or contest their location within varna schemes (Quigley 1994). So which is really caste? The answer is none of them, or all of them, because the meanings and forms of caste change over time and between persons.

Allowing for changing caste identities, but only between groups, assumes individuals to be miniature reproductions of their communities (Turner 1976: 989). This assumption arises from the tendency to collectivise. Exhibiting such collectivist thinking is Unnithan who shows how the Girisias of Rajasthan are considered a Rajput caste by themselves but a tribe by others (Unnithan 1994). Among those conventionally described as tribes, Parkin observes that Juang and Hill Bhuiya identify themselves as a caste, Santal imitated caste society previously but now consider themselves a tribe, and another group discards 'caste' and 'tribe' in favour of 'indigeneity' (Parkin 200o). In Uttar Pradesh, Tharu and Buxa insist they are distinct despite their many similarities; but despite significant cultural 
and linguistic differences, groups across the border in Nepal insist they are all Tharu (Guneratne 1998). In each of these cases, and those mentioned in the introduction, caste identity is shown to be contested and amenable to change, but individuality is denied.

This devalues persons and restricts our understanding of how fluid caste identity can actually be. As Quigley says:

To set out with the idea that castes are, in general, bounded groups with a fixed membership is to embark on a path of endless frustration.... Sometimes the boundaries... are relatively unambiguous; sometimes they are extremely fuzzy. Sometimes it is relatively straightforward to say who belongs to a caste and who does not; sometimes it is impossible (Quigley 1993: 9).

Shyamlal's analyses of how high and low caste persons accept membership of Untouchable castes (Shyamlal 1992, 1995, 1996, 1997) is a refreshing contrast to the collectivist examples mentioned so far. He finds that conversion is usually an individual process, with converts coming from Banias, Brahmins, Charans, Jats, and Rajputs, and being accepted by different Untouchable castes like Bairwa, Balahi, Bhangi, Chamar, and Mahar (Shyamlal 1997). These studies prove that persons can change their caste names and statuses independently of groups. This conclusion also contrasts the tenets of Sanskritisation - the emulation of dominant castes-which say little about name changes and hold that status mobility is the privilege of collectives (Srinivas 1989). Like Shyamlal, we study changes in caste names and statuses, with individuals as the central unit of analysis. Unlike him, however, our focus is on outcasting rather than downcasting; how Brahmins become Non Brahmins (and vice versa) rather than how Brahmins who become Non Brahmins are accepted into other castes.

Another study germane to this essay examines Muslims in Hyderabad (Ali 2002). In it, Ali argues that there is a shift from caste as primarily a communal identity to caste as primarily an individual identity, and that studies of the link between these levels of identity is absent in caste discourse (Ali 2002: 594). Like him, we focus on individuals and examine the transition of 'Brahmin' from a personal to social identity. In contrast, however, his work relies on ethnographic description while ours is oriented towards individuals' thoughts and their 'structure of ideas' (Barnett 1975: 151; Das 1987: 2). Ali's respondents also treat caste, class, and religion as ethnic identities (Ali 2001). Supporting this shift to caste/ethnicity, Sheth 
says that 'the feeling of belonging to a caste is now expressed more in the nature of community consciousness' (Sheth 2000: 244). These positions reinforce Barth's observations, made 35 years earlier, that 'the boundaries of caste are defined by ethnic criteria' (Barth 1970a: 27).

Central to ethnicities is the principle that individuals' identities change when the person's performance is good or poor (in his or others' eyes) and alternative identities are available (Barth 1970a). Nagel terms this individual ethnic renewal (Nagel 1995: 947-94). Such renewal implies that individuals impose normative expectations of caste identity on themselves and others. The choice to adhere to, adapt, or opt out of these scripts is theirs as well; but others will inevitably try to influence or restrict these choices (Song 2003: 43). Another central principle is that despite flows of people across them, boundaries persist (Barth 1970a, 197ob). So, even if a hundred people change their caste identities from Brahmin to Non Brahmin, the category 'Brahmin' will persist as a unit of inclusion/exclusion as long as Brahmin identity remains salient in that context. As we move from villages to cities, from India to the diaspora, the key question is whether caste identities will remain salient.

Ample empirical evidence suggests that they do. Nagel argues that salience is a function of interactional relevance; identities are hidden when not immediately relevant (Nagel 1994: 154-5). Especially in contemporary diasporic cities where it is overshadowed by other referents, caste identity is rarely displayed or emphasised publicly. For example, in Singapore, 'Brahmin' is usually subordinated to other categories like 'Hindu', 'Indian', 'Tamil', or 'Singaporean'. However, although they are often muted, caste identities in the diaspora are not extinct or close to extinction. They manifest in private spaces, like family and marriage, and in public spaces, during Indian social or religious activities. They are also perpetually reconstructed. This reconstruction results from the continual building and rebuilding of psychologies, institutions, history, politics, and culture by members and non members (Nagel 1995:948) in the host nations. These diverse influences-coupled with the absence or weakening of prescriptive authorities like family, local councils, and caste associations-allow caste identities in the diaspora to take more heterogeneous forms, and shift more rapidly between individuals, than is likely in Indian villages.

In Mauritius, for example, caste is interpreted locally through varna categories. But this scheme is radically different from that described in Sanskrit texts. The categories and corresponding statuses in it are: 
Brahmin/Babujee (high), Vaish (middle), Rajput (low), and Ravived (low) (Hollup 1994, p. 301). Rajput, generally considered a high caste in India, is considered low caste here (Hollup 1994: 310). Priesthood, traditionally a Brahmin occupation, is, in Mauritius, an achieved status divorced from birth ascription (Hollup 1994: 312). Hierarchy, commensality, diet, and endogamy are also non existent or porous properties (Hollup 1994). Individual mobility is a central feature of this system; claims to membership of a particular caste do not even require recognition or validation from anyone else (Hollup 1994: 303). Though it is not applicable in many social domains and 'there is hardly anything to distinguish members of the different caste population', caste paradoxically remains an important identity to Hindu Mauritians (Hollup 1994: 314-15).

In Canada, Indo-Caribbean identities based on caste, Indian languages, and sub-regional origins are conflated to reflect an ongoing process of Re-Indianisation (Singh 1997). So, fragments of caste ideology persist, but not as any distinct empirical reality (Singh 1997). Individual ethnic renewal among the population studied by Singh is driven by the members themselves, the charismatic influence of one community leader, and the institutional presence of a temple (Singh 1997). In contrast, among some Indian Americans, caste is a distinct marker of Indianness, though no central authority prescribes it thus. For them, being able to name one's caste indicates knowledge of lineage back to India (Pathak 1998: 121 ). Caste practices continue to be performed as well; to different degrees depending on individual or family predilections (Pathak 1998, p. 121 ). Asking a random sample of 576 Indian Americans their caste affiliation, Pathak finds that only 83 respondents either did not respond, did not know the answer, felt caste was not applicable to them, or did not believe in caste (Pathak 1998: 122). The rest, constituting $85 \%$ of the sample, self identified themselves with one of 38 distinct castes (Pathak 1998: 122). In South Africa, the post apartheid state attempted to impose group (Indian, African, White, etc.) and supragroup (Blackness, Multiracialism, Nonracialism, etc.) identities on its population through discourse and policy (Dhalla 2000). Ironically, these strategies made caste distinctions more significant to Indians there, as they actively resisted the imperative to assimilate (Dhalla 2000: 269). In each of these examples, diasporic caste identities are realised differently, but remain salient to Indians in the host nations and allow individuals more freedom than is generally possible in village India. 
In Singapore, Indians currently comprise 8\% (293, 100 people) of the resident population (citizens and permanent residents) (Singapore Department of Statistics, March 2005, Table 2.2). Chinese (76\%), Malays (14\%), and Others (2\%) constitute the rest (Singapore Department of Statistics, March 2005, Table 2.2). Most Indians in Singapore are descendants of job seeking immigrants from South India who arrived in the $19^{\text {th }}$ and early 20 th centuries. In recent years there has also been an influx of professionals from the subcontinent. Many of them eventually take up permanent residency or citizenship. The rubric 'Indian' is misleading because it camouflages significant linguistic, religious, national, sub national, class, and caste cleavages amongst people of South Asian origin. South Indian Tamil Hindus are the dominant bloc, comprising at least $60 \%$ of Indians in Singapore. Though statistics are unavailable, the numbers of North Indians and Sri Lankans are also substantial. These cleavages are not, however, officially acknowledged by the Singapore government. So, in public discourse, 'Indian' remains the key referent for these people. Policies enforcing meritocracy and desegregation also mean that Indians do not cluster in occupational niches and residential enclaves.

Amongst Hindu, Muslim, and Christian Indians in Singapore, there are hundreds of castes. The Chettiars are easily the most prominent. They are Hindu Indians subdivided into exogamous clan groups, each affiliated with one of nine temples in Tamilnadu (Evers and Pavadarayan 1993: 850). Traditionally, many of them worked as traders and moneylenders. A large Hindu temple has been owned and managed by them since its foundation in 1869 . This is unique because most other temples have been subordinated to a statutory body-the Hindu Endowment Board. Thaipusam, a Hindu festival made infamous by devotees' (none of them Chettiars) practice of skewering themselves with metal hooks, is sited here. This temple is also the focal point for the Chettiars' religious and social activities; it helps maintain the strong sense of belonging and camaraderie they exhibit even today. Musuguntha Vellalars are another Hindu Indian caste in Singapore. To them, a translocal connection with their 'home village' in India is crucial to preserving their sense of identity and community. This takes the form of owning and frequently visiting a functioning, modern house in the village (Velayutham and Wise 2005: 32). While caste remains salient to these and other Indians in Singapore, the degree of salience and mechanisms by which it is realised vary significantly between individuals and groups. 
Brahmin and Non Brahmin identities are not salient to all Indians in Singapore. To some, caste does not matter. To others, caste matters, but these identities do not. However, this group is likely to be small, and its members are probably Indian Muslims or Indian Christians who practice caste, but see 'Brahmin' and 'Non Brahmin' as unimportant categories. So, only a subset of Indians engages these identities; then too, only some of the time, in some ways. This subset includes those with Brahmin family, friends, or enemies; those who locate their caste within a continuum which includes the categories 'Brahmin' and 'Non Brahmin'; those who talk about Brahmins and Non Brahmins; those with knowledge of Brahamanas; and so on. Henceforth, 'Indian' is used in this restrictive sense, as convenient shorthand referring to those who are linked to Brahmin and Non Brahmin identities in Singapore.

To date, the only study of Brahmins in Singapore was carried out by Govindasamy in 1975 (Govindasamy 1975). She compared the attitudes of older and younger Brahmins towards caste practices. Specifically, factors like vegetarianism, friendship networks, dating preferences, marriage taboos, religiosity, and wearing of the sacred thread were investigated; purity and pollution were deemed irrelevant to caste in Singapore (Govindasamy 1975:45). Unsurprisingly, older Brahmins were found to be more orthodox-most were vegetarian, had married only Brahmins, participated in Brahmin rituals, and recited required prayers - than the younger generation. The role of the only caste association for Brahmins - the Singapore Dakshina Bharatha Brahmana Sabha (SDBBS) — was analysed as well. This association was formed in 1924 to cater to the needs of its members, and is administered by an executive committee voted in at annual general meetings. It disseminates monthly newsletters, employs priests from India to perform rites, and organises religious and social functions (see www.sdbbs.org for more information). Govindasamy found that most of SDBBS' activities were religious and of little relevance to the younger generation. Concluding her study, she hypothesised that since caste practices were weakening, Brahmin identity was in danger of losing its salience in Singapore.

While useful as an introduction, this study is replete with flaws that restrict its value. Repeatedly, Govindasamy emphasises that caste is a Hindu identity, caste is varna, and caste in Singapore is merely an extension of that in India. The first two are parables we have criticised earlier. The latter is an inadequate lens within which to study diasporic caste identities. While it may be influenced by its roots in India or 
elsewhere, each manifestation of caste must be understood as a route, a unique journey in itself (Woodward 2002). Brahmins in Singapore cannot simply be equated to or judged against their counterparts in India. Stereotypical ethnic markers like vegetarianism, wearing of sacred thread, religious knowledge, priestly occupations, and spatial segregation do not even circumscribe the heterogeneity amongst the latter. So, limiting the definition of Brahmin identity in Singapore to only these markers is misguided and misleading. As we will argue, when approached as a route it becomes clear that Brahmin identity and community are not in any danger of losing their salience to Indians in Singapore.

Methodologically, the definition of Brahmin was not problematised by Govindasamy either. She assumed that all SDBBS members are automatically Brahmins. This does not account for many members' belief that other members are not Brahmins. Further, according to her, there were exactly 127 Brahmin families in Singapore at the time of the study. 105 of these were SDBBS members (in 2004 there were 780 members) while 22 were not (Govindasamy 1975: 11). The latter were not members because their household heads were not male. This rule restricting membership to male household heads has since been repealed. The repeal was motivated by petitions from a small number of households, in which the male head had passed away, thereby leaving their widows and young children suddenly excluded from SDBBS' activities. There are now no gender restrictions on membership, though, in 2004, there were only 18 female members, signifying that cultural taboos are still in place. Even if the assumption that all SDBBS members are automatically Brahmins is upheld, the figure 127 (or the current 780) does not include South Indian Brahmins who choose not to join the association (many Malayalee and Telugu Brahmins in Singapore are not members), North Indian Brahmins (SDBBS membership is restricted to Brahmins of South Indian origin), and Brahmins among the transient Indian population (comprised of students and adult workers). Further confusion arises because the identities of individuals in these excluded groups are also contested. It is difficult, therefore, to definitively state that someone is Brahmin or Non Brahmin, based only on what they say about themselves, or what someone else says about them. Until the question of who is a Brahmin is resolved, we suggest it is more precise to think in terms of insiders and outsiders. Insiders are defined as Indians in Singapore who consider themselves Brahmin. Outsiders are defined as Indians in Singapore who consider themselves Non 
Brahmin. The boundaries of caste identity are never self determined; they are drawn by individuals within and without. So, to accurately understand Brahmin identity and community, insiders' and outsiders' views must be considered.

\section{Research Design}

Cases are bounded systems defining what is being studied (Stake 2000: 436). Here, the 'what?' refers to Brahmin identity and community. The boundaries of this study are Singapore (spatial), the present (temporal), and Indians' cognitions (perceptual). This is an explanatory case (Yin 2003: 5) that concentrates on generating a model, not thick description. Since this model is grounded in a single context, its value is intrinsic (Stake 1995: 3). So, conceptual and substantive generalisations to other cases can only be hypothesised. Data collection was implemented in two stages. The purpose of the first was to identify and explore relevant issues for further study in the second. In the first stage, implementation was sequential, with a qualitative instrument (participant observation) preceding a quantitative one (pilot survey). In the second stage, implementation was concurrent, with qualitative (participant observation, unstructured interviews, and seminar) and quantitative (final survey) instruments being employed simultaneously. In both stages, however, the qualitative instruments were employed more extensively. Over the one year period in which this study was conducted, an approximate total of $15^{\text {o responses were }}$ collected (through one instrument or another). However, only 43 of these responses came from outsiders (40 of them from the final survey).

\section{Who is a Brahmin in Singapore?}

\section{A Simple Answer}

'A Brahmin is someone born to Brahmin parents' is the simple and common answer most Indians give to this question. This response is, however, unsatisfactory. It uses circular logic to argue that Brahmins come from Brahmins. All we know, therefore, is that once someone is a Brahmin, then his or her children are Brahmins. An infinite regress, in which the parents have Brahmin parents, and the 
grandparents have Brahmin parents, and so on and so forth, soon follows. Our understanding of this identity does not improve, because no independent properties of it are given. The sense of biological determinism evoked by this response also obscures the fact that heritability is modifiable by action (Smaje 2000: 182). For example, eating meat, marrying a Non Brahmin, or converting religion are actions that may result in the children of Brahmin parents becoming Non Brahmins. Another flaw is that we are not told what happens when one parent is Brahmin and the other Non Brahmin. Are their children Brahmins or Non Brahmins? In spite of these failings, this answer would be acceptable if indeed Indians think this way. We believe they do not. The reality is more complex.

\section{Complex Answers}

One answer is not enough. According to the person, time, and situation, different responses will emerge. It is futile either to find a single definition or try to circumscribe them all. 'The more we seek fixity and certainty the more troubling' (Woodward 2002: $\left.{ }_{15} 8\right)$ socially constructed identities become. Instead, understanding Brahmin identity in Singapore means asking 'how' this identity is assigned, not 'what' it is. This focus on mental processes allows theory to be generated even when outcomes are uncertain. Explicating these processes is difficult because they are not directly observable, people may be unaware of how they think, or may deliberately conceal their true thoughts. Nevertheless, this study is our attempt to 'look behind public statements and seek the normative understandings expressed in private discourse' (Sharma 1999: 33). Figure 1 represents the model by which we think Indians think about Brahmin identity in Singapore. This model is the final iteration in a series of models successively refined or rejected outright through member checks.

The numbers in each quadrant represent classes. 1st class is the archetypical Brahmin while $4^{\text {th }}$ class is the antithetical Brahmina Non Brahmin. 2nd and 3 rd classes are transitional statuses. The former is considered a deviant Brahmin; the latter is seen as a Non Brahmin who is more deviant than 2nd class but is less so than $4^{\text {th }}$ class. Indians think in terms of these classes though they label them differently or not at all. Alternative labels tend to be binary and include: good and bad, pure and impure, traditional and modern. Within these alternative labels there are usually subdivisions roughly corresponding to the different classes. Some Indians may think in 


\section{Minor}

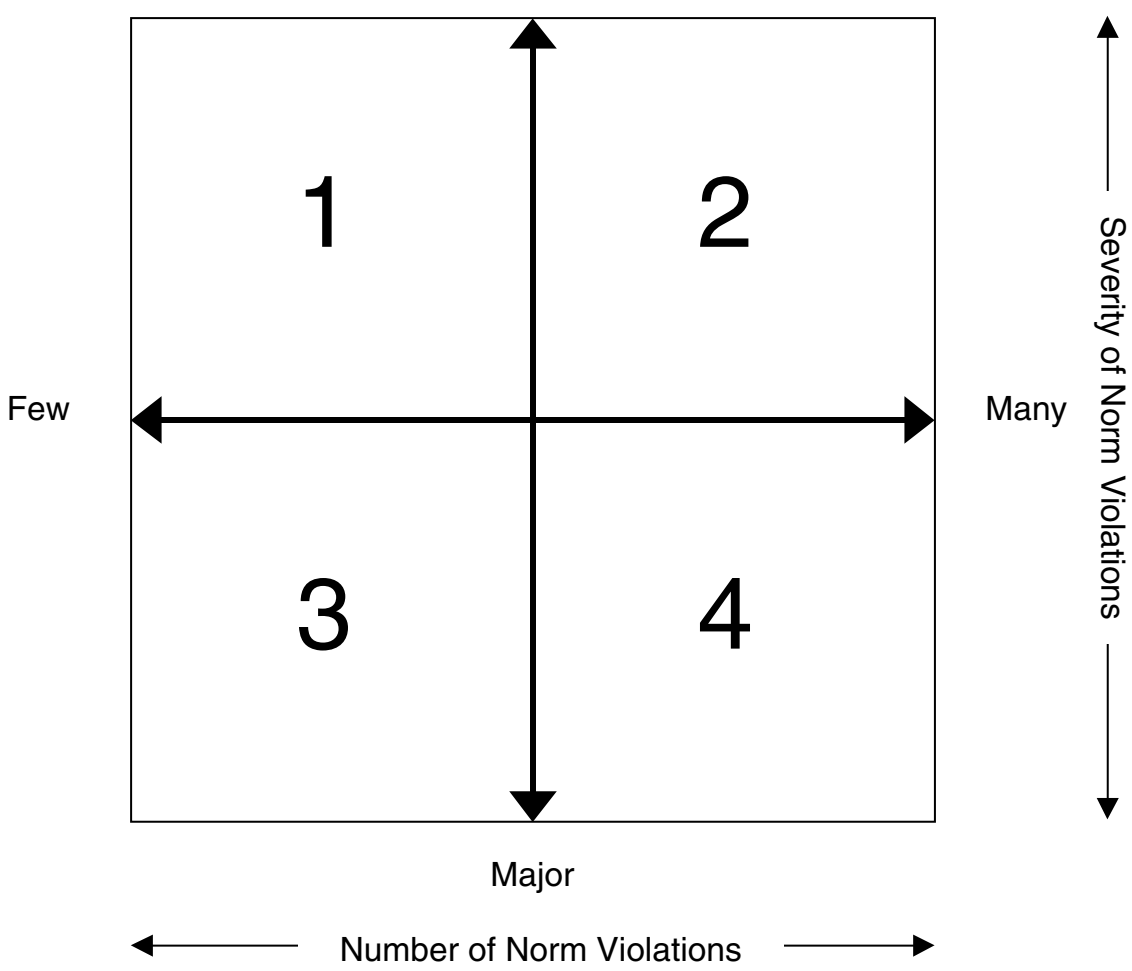

Figure 1. Stakeholders' Cognitive Model of Brahmin Identity.

terms of more than four classes. In most of these cases we think the additional classes can be subsumed under the four we have proposed.

In routine interactions, these classes are never stated explicitly; they can only be inferred through words and behaviour. They also refer to degrees of belonging and difference, not hierarchical ranks. So, a $4^{\text {th }}$ class person is not seen as inferior, or more polluted, than a 1 st class one. Some surely do think in terms of purity and pollution but we are convinced their numbers are negligible. Further, while they do not volunteer this information, Indians, if asked, will not hesitate in saying whether they judge someone to be Brahmin or Non Brahmin. Those classified as 1 st or 2nd class are always considered Brahmins; those classified as $3^{\text {rd or }} 4^{\text {th }}$ class are always considered Non Brahmins. This binary opposition between Brahmins and Non Brahmins may seem 
simplistic. It is. This, however, accurately reflects Indians' cognitive reality. When discussing Brahmin identity they think only of Brahmins and Non Brahmins - who to include versus who to exclude-not the myriad caste identities that constitute either of these super ordinate categories.

Each class is a role. Insiders and outsiders determine and enact these roles; they judge, and are judged, by themselves and others. Roles are contested; when different people simultaneously judge an individual's identity to be different, he occupies two or more roles at once. So, an individual may, at the same time, be judged 1st class by his family, 3 rd class by his friends, and 2nd class by himself. Roles are also renegotiated over time. Someone who is considered 1 st class today may be reclassified as 2 nd class tomorrow by the same judge.

Consistently, two criteria, the number and severity of norm violations, emerged as vital to decisions concerning Brahmin identity. An individual perceived to commit many, major violations is always deemed $4^{\text {th }}$ class, while one with only a few, minor violations is always deemed 1 st class. While the four classes, number of violations, and severity of violations remain stable components of decision making, the following are subject to differences of and changes in opinion, and lead to role contestation and renegotiation:

- The actions and attributes that are considered salient

- The content of normal and norm violating states of each action and attribute

- The definitions of 'few' and 'many'

- The definitions of 'minor' and 'major'

- The knowledge of actors' norm violations

Seven actions and attributes feature prominently when deciding who is or is not a Brahmin. They are listed below, together with their corresponding normal and norm violating states enclosed in parentheses.

- Religious Identity (Hindu/Non Hindu)

- Parents' Caste Identity (Brahmin/Non Brahmin)

- Place of Origin (Singapore/Other Countries)

- Dietary Preferences (Vegetarian/Non Vegetarian)

- Spouse's Caste Identity (Brahmin/Non Brahmin)

- Nurture (Raised a Brahmin/Raised a Non Brahmin)

- Religious Rituals (Brahmin Rituals/Non Brahmin Rituals) 
TABLE 1

Few, Many, Minor, and Major

\begin{tabular}{|c|c|c|c|c|c|}
\hline $\mathrm{S} / \mathrm{n}$ & Action/Attribute & Norm & Norm Violation & Severity & Number \\
\hline $\begin{array}{l}1 . \\
2 .\end{array}$ & $\begin{array}{l}\text { Religious Identity } \\
\text { Parents' Caste } \\
\text { Identity }\end{array}$ & $\begin{array}{l}\text { Hindu } \\
\text { Brahmin }\end{array}$ & $\begin{array}{l}\text { Non Hindu } \\
\text { Non Brahmin }\end{array}$ & Major & $\begin{array}{l}\text { 1 violation } \\
(\mathrm{Few})\end{array}$ \\
\hline 3 . & Place of Origin & Singapore & Other Countries & Major or & \\
\hline 4 . & Dietary Preferences & Vegetarian & Non Vegetarian & Minor & \\
\hline 5 . & $\begin{array}{l}\text { Spouse's Caste } \\
\text { Identity }\end{array}$ & Brahmin & Non Brahmin & & \\
\hline 6. & Nurture & $\begin{array}{l}\text { Raised a } \\
\text { Brahmin }\end{array}$ & $\begin{array}{c}\text { Raised a Non } \\
\text { Brahmin }\end{array}$ & & $\begin{array}{l}7 \text { violations } \\
\text { (Many) }\end{array}$ \\
\hline 7 . & Rituals & $\begin{array}{l}\text { Brahmin } \\
\text { Rituals }\end{array}$ & $\begin{array}{l}\text { Non Brahmin } \\
\text { Rituals }\end{array}$ & Minor & \\
\hline
\end{tabular}

Many Indians, however, feel that particular actions and attributes ought to be excluded from or included in this list. For example, 'I don't think diet has anything to do with being Brahmin', said one. 'SDBBS membership is important; as long as SDBBS considers you a Brahmin you are, if not you are not', said another. Place of Origin also means different things to different people. To some, it refers to country of birth. To others, it refers to country of residence prior to coming to Singapore. Normal and norm violating states are problematic as well. One reason is that they are ambiguous. For instance, the term Hindu describes incommensurable traditions ranging from Tantra to Hare Krishna. Vegetarianism is also disputed with some saying that eggs constitute meat and others disagreeing. Another reason these states are problematic is that four of them are prescribed in terms of Brahmins and Non Brahmins; this certainly exemplifies the circular logic discussed earlier.

People also change their minds. 'For many years I felt diet was part of Brahmin identity, but now I don't think so anymore', is one response illustrating this. 'I used to consider eggs as vegetarian, but now I don't', is another. These opinions are also shaped, in part, by opinions of family and friends, which are themselves always changing. So, the potential for dissensus, over the salience of particular actions and attributes, and content of normal and norm violating states, is large. Consequently, it is unsurprising that individuals are assigned different classes, by different judges or by the same judge at different times. Definitions of the terms 'few', 'many', 'major', and 'minor' are also subjective. If the list of common actions and attributes suggested earlier is used as a basis, we believe many Indians' classifications would be similar to that represented by Table 1 . 
Individuals' definitions of these terms also arise and change due to three inputs apart from the actions and attributes, and content of normal and norm violating states themselves. First, judges observe whether individuals consider themselves Brahmin or Non Brahmin. For example, children from mixed marriages are often classified as

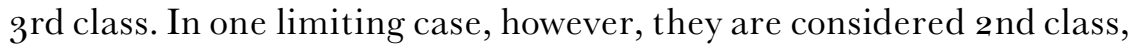
by themselves and most others, simply because in their beliefs and actions they make it clear they consider themselves as such. Second, what reference groups such as family and friends say is also influential. In another mixed marriage, a mother disowned her son for marrying a Chinese. Her actions make it more likely that her grandchildren from that marriage are considered $3^{\text {rd }}$ or $4^{\text {th }}$ class. Third, judges utilise personal criteria which vary widely. 'If a Brahmin woman marries a Non Brahmin, she is no longer Brahmin; the other way around is okay, he would still be Brahmin', says one respondent. This gender bias has roots in broader Hindu traditions where males are usually seen as the active determinant of identity. However, as our final survey shows, not every Indian thinks this way.

Our point is that the meanings of the terms 'few', 'many', 'minor' and 'major' are never definitive; they constantly change. This inevitably leads to variances, between judges and with the same judge over time, in ascribing Brahmin identity.

Perfect information exists only in the minds of economists. In reality, not everyone knows everything. So, someone may be classified as 1st class even though he is engaged in all sorts of norm violations, simply because the classifier unaware of them. Deception, which is the withholding of information or provision of misinformation to others, also affects judges' knowledge of norm violations. Illustrating this is James, a former insider who successfully hid his conversion to Christianity from his family and friends for over two years. Self deception applies when actors' cognitions about their identity lie so deep that they are not consciously aware of it (Beteille 1996, p. 176). For instance, when his daughter wanted to marry a Non Brahmin, one parent realised he could not accept it. This realisation stunned him because until then, 'open minded' was how he characterised himself.

\section{Summary}

To reiterate, the complex cognitive model of how Brahmin identity is determined in Singapore makes three claims. First is that insiders and 
outsiders are sorted into one of four classes by themselves and others. Second is that this sorting depends on the number and severity of norm violations. Third is that differences or changes in judges' perceptionsover which actions and attributes are salient, the content of normal and norm violating states that correspond to each action and attribute, the definitions of 'few' and 'many', the definitions of 'minor' and 'major', and the knowledge of actors' norm violations-affect which class an individual is ascribed, but does not affect the first two claims.

Sceptics will contend that our first two claims are unsubstantiated assertions. Verifying this model is not straightforward, however, because nearly all those we encountered were not immediately aware of how they determine who is or is not a Brahmin. It became apparent early on that most had never seriously reflected on this question before. Their reflexive answers were confusing and very often contradicted what we heard them say or saw them do. Prior to the final survey, for example, we asked every respondent if a Brahmin could become a Non Brahmin and vice versa. $5^{8 \%}$ answered that caste identity was always immutable and then contradicted themselves at least once during the rest of the survey. Strikingly, only two respondents even realised their answers were inconsistent. So, simply asking Indians how they think is not enough. We believe a better way to verify this model is discussion. After explaining and advocating it, we let respondents answer why they think it is right or wrong. The next section presents these accounts of their agreements and disagreements.

Assuming that it is valid, the model is also limited since it cannot give specific answers. It cannot take a random Indian, find out information about him, and then predict with certainty how any other person will classify him or how he will classify himself. This limitation, however, is not a flaw. Essentialist answers are unlikely to be correct as they cannot accommodate the complexities of reality. So, the model's value is that it explicates the stable components of individuals' cognitions while simultaneously allowing for multiple situational answers within its framework.

\section{Model Verification}

Reactions to the model are presented here. These seven testimoniesone is a table summarising the results of the final survey, four deal with particular actions and attributes, and two address the model as a whole-enhance their authors' understanding of Brahmin identity 
and allow the reader to share vicariously in the experiences therein (Denzin 1989: 83). We have selected only seven testimonies due to space constraints. In total, 13 were recorded. Of these, two rejected the model's validity. The rest agreed with it. These respondents had no problems discussing their experiences or perceptions via its components; in some cases they suggested modifications. Unlike the other testimonies, the final survey results are not a reaction to the model. Instead, they represent a collective view that was influential in its construction. Following these testimonies, the presence of social controls is analysed. This analysis shows that the model also acts as a loose social structure which enforces norms by limiting violations. Combined, we believe that testimonies and social controls provide sufficient evidence to verify the model.

\section{Testimonies}

The first testimony is an account of one of this manuscript's author's changing Dietary Preferences. It shows how these changes affect what others think of him and what he thinks of himself. Beginning with an author's biography contextualises this study in his experience and reemphasises that he is an Indian inextricably embedded in this case. This is followed by Table 2 which summarises the results of the final survey. Numbers in this table reflect percentages. Question 12 should have been asked to make the survey comprehensive, but was omitted due to an oversight.

During my sacred thread ceremony I remarked that all vegetarian boys had to go through this ritual. Having never eaten meat before, I considered myself 1 st class, as did most others. Two years later I had my first McDonald's Big Breakfast. From then I regularly ate meat outside the house; my favourites were mutton and chicken. At this point I considered myself 2nd class. My orthodox grandmother did not know about my new diet (more likely she pretended not to know); if she did she would have classified me as 3 rd class. Later, during a trip to New Zealand I must have eaten 30 different kinds of steak in 30 days. When I related this to some of my friends they immediately began condemning me for eating beef. In their eyes this had violated a

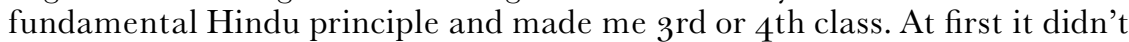
matter to me, but after a while the social pressure made me stop. Later, for health reasons, I went back to being vegetarian. Now, most people consider me 2nd class. I have no intention of becoming 1 st class again. Being 2 nd class gives you sufficient status without the attendant problems of being too pure.

The third testimony is one respondent's account of two mixed marriages. Both involve male insiders marrying outsiders, but the 
TABLE 2

Final Survey Results

\begin{tabular}{|c|c|c|c|c|}
\hline$\overline{\mathrm{S} / \mathrm{n}}$ & Determinants & Questions & Yes & $\mathrm{No}$ \\
\hline \multirow[t]{6}{*}{$1-2$} & \multirow[t]{2}{*}{$\begin{array}{l}\text { Dietary } \\
\text { Preferences }\end{array}$} & $\begin{array}{l}\text { Is a Brahmin who eats meat } \\
\text { considered a Non Brahmin? }\end{array}$ & 54 & $4^{6}$ \\
\hline & & $\begin{array}{l}\text { Is a Non Brahmin who does not eat } \\
\text { meat considered a Brahmin? }\end{array}$ & 11 & 89 \\
\hline & \multicolumn{4}{|c|}{ When a Brahmin male marries a Non Brahmin female: } \\
\hline & & Does he become a Non Brahmin? & 11 & 89 \\
\hline & & Does she become a Brahmin? & 14 & 86 \\
\hline & & Are their children Brahmin? & 63 & 37 \\
\hline & When a Brahr & in female marries a Non Brahmin ma & & \\
\hline \multirow{3}{*}{$3^{-8}$} & Spouse's Caste & Does she become a Non Brahmin? & 43 & 57 \\
\hline & Identity/Parents' & Does he become a Brahmin? & 1 & 99 \\
\hline & Caste Identity & Are their children Brahmin? & 19 & 81 \\
\hline \multirow[t]{2}{*}{$9-10$} & \multirow[t]{2}{*}{ Nurture } & $\begin{array}{l}\text { If a Brahmin couple adopt a Non } \\
\text { Brahmin child does the child } \\
\text { become Brahmin? }\end{array}$ & 68 & 32 \\
\hline & & $\begin{array}{l}\text { If a Non Brahmin couple adopt a } \\
\text { Brahmin child does the child } \\
\text { become Non Brahmin? }\end{array}$ & 54 & $4^{6}$ \\
\hline \multirow[t]{2}{*}{$11-12$} & \multirow[t]{2}{*}{ Religious Identity } & $\begin{array}{l}\text { Is a Brahmin who converts to a } \\
\text { religion other than Hinduism } \\
\text { considered a Non Brahmin? }\end{array}$ & 79 & 21 \\
\hline & & $\begin{array}{l}\text { Is a Non Brahmin who converts to } \\
\text { Hinduism considered a Brahmin? }\end{array}$ & $*$ & * \\
\hline \multirow[t]{2}{*}{$13^{-14}$} & \multirow[t]{2}{*}{ Religious Rituals } & $\begin{array}{l}\text { Does a Brahmin who follows no } \\
\text { Brahmin rituals become a Non } \\
\text { Brahmin? }\end{array}$ & 35 & $6_{5}$ \\
\hline & & $\begin{array}{l}\text { Does a Non Brahmin who follows all } \\
\text { Brahmin rituals become a } \\
\text { Brahmin? }\end{array}$ & 34 & 66 \\
\hline
\end{tabular}

first family abandons Brahmin identity while the latter tries to retain it. The actions and attributes discussed are Spouse's Caste Identity and Parents' Caste Identity. Following this is a narrative by a different respondent. This testimony illustrates the difficulty of deciding whether a particular member of the Hare Krishna cult is Brahmin. Specifically, the impact of Religious Rituals is examined.

Iyer is now $4^{\text {th }}$ class because he married a Chinese. His children are the same. Ambi is now 3 rd class because although he married a Non Brahmin; at least she is Indian. Also, he tries to keep up with Brahmin rituals. Of course if you ask them you will get different answers. Iyer doesn't care about caste, but probably thinks of himself as 2nd class. On the other hand, Ambi likes telling everyone he is 1 st class. Ambi's children are either 2 nd class or $3^{\text {rd }}$ 
class. They follow all the Brahmin ways, but I don't know if it is voluntary or not. Maybe they are just doing it to please their dad. You know it's funny; if a Brahmin woman married a Non Brahmin, even if she wanted her children to be Brahmin they could not be, because society would not accept this. Of course I don't believe this. My view is that if the children follow all the rules voluntarily then whether the father or mother is Brahmin the children can become 2nd class, but they can never be 1 st class.

In my opinion and his, Hari is at least 2nd class. This is because although he was not born in a Brahmin family, by the spiritual activities he has undertaken in the later part of his life he has reached a high platform. 1st class is someone who has reached the platform of transcendence. 2nd class is one who is engaged in the process of becoming 1 st class. Birth is just a tool to be a 1 st class Brahmin, not a precondition. Hari is vegetarian and participates in the required Brahmin rituals like chanting the 'gayatri mantra' three times daily. Most importantly, he is doing the job of a Brahmin. The duty of a Brahmin is to disseminate spiritual knowledge and live on charity accepted from doing this, and Hari exemplifies this. But if you ask those born into Brahmin families they won't agree with me. They will say that he is 3 rd class.

Place of Origin is particularly contentious. Many Indians born and raised in Singapore dislike new (though the definition of 'new' is elastic) expatriates, especially those born and raised in India. So, though they admit that the latter are more orthodox and enthusiastic, expatriate Brahmins are often derided as 2 nd class. It is also likely that many expatriates consider 'locals' unorthodox and unenthusiastic, and in turn deride them as 2nd class or worse. This conflict illustrates how existing notions of identity can be destabilised by new arrivals. Since the influx of Indian professionals (from India and the diaspora) to Singapore is increasing steadily, this issue will become more significant in the future. Yet, open discussion about this is non existent at present. Even at the seminar, talking publicly about this divide was deemed taboo. In private conversations and via gossip, however, it remains a source of tension. The next testimony reflects part of this conflict; notable is that this respondent rejects our model. If his self assessment is accurate-we think it is—then our model is limited. While many insiders and outsiders sort themselves into four classes, and do so via the number and severity of norm violations, clearly, others do not. So, the model cannot be applied to all Indians.

Q: When did you come to Singapore?

A: I came from India about 25 years ago and have been here ever since. I'm also a Singapore citizen now.

Q: Are you accepted as a Brahmin in Singapore?

A: Hard to say, probably not fully. I think your earlier description is right. 
Those born here don't fully accept me; they think I am an expatriate. Those newly arrived consider me a local. I'm stuck in between. But your model is wrong. These ideas of 1 st class, 2nd class, etc. don't make sense to me. I think there are only two divisions, Brahmins and Non Brahmins. If you are a Brahmin then you are always Brahmin. Just because I'm from India does not mean I'm Non Brahmin. But there is a divide between local Brahmins and expatriate Brahmins.

Q: OK. What about Madhavan? He is a Malaysian and lives there. Is he a local or expatriate Brahmin?

A: That's the funny thing. Although he doesn't live here, he visits often because he has relatives. So, many people think he is a local Brahmin. Trisha also; she was born here but went overseas to study at the age of eighteen and has never returned except for brief visits. Yet, she is more of a local than I am.

The remaining testimonies address the model as a whole. The first accepts its validity but expresses reservations over the number of classes listed. As mentioned, we believe that even if some Indians think in terms of more classes, they can be subsumed under the four we have proposed. This respondent also suggests, and we agree, that another survey can be carried out to provide further evidence of the model's validity. The second testimony argues that both 'simple' and 'complex' answers are valid at different times. This is an important insight, which will be taken further in section six. It hints that Brahmin identity might be situationally shaped to be unitary some of the time and fragmented at others.

OK. I understand what you are saying. Based on intuition, I think your explanation makes sense. But I think some things should be changed. Firstly, are you sure there are only four classes or is that just a convenient number? I think that different people think in terms of different numbers of classes. Secondly, I think you need to do a separate study to further confirm whether your stable components are actually stable. Maybe another survey of some kind?

It's not that we say one thing and think another. Usually, we don't think. We just believe that Brahmins are always Brahmins. But if we consider it a bit more in depth, like I am doing now, then we realise that Brahmins are not always Brahmins. But it's too difficult to think so hard all the time. So we forget about deep thinking and go back to the simple idea that Brahmins are always Brahmins. So, it's not that one belief is right and one is wrong. It's that sometimes one is right, sometimes the other is right.

\section{Social Controls}

The model is also a loose social structure which rewards compliance and punishes deviance by administering positive and negative social 
sanctions respectively. 'What are the sanctions available to the caste or subcaste today to ensure the conformity of the individual with the codes prescribed by it?', asks Beteille (Beteille 1996: 150-1). Here, labels (1 st class to $4^{\text {th class) }}$ are the sanctions. Since the labels assigned a particular actor are always shifting, it is obvious that social controls are weak.

Those judged 1st class are accorded elevated status because they exhibit supra conformity (Heckert 2003: 35) by complying with norms more dutifully than most. Public pressure is a positive sanction that forces these actors to live up to their role expectations in order to retain approval. Priests hired by SDBBS are usually seen as 1 st class. Most comply with six of the seven norms discussed. Although their Place of Origin is India, this violation is made up for by the privileged position of their occupation; an imbalance is thus made up for by reprioritising elements of status. They conduct religious classes, are sought after at religious functions, and are generally held up as exemplary. For them, public violation of norms is difficult because this would undermine their role. Interestingly, at a recent funeral ceremony one priest deliberately cheated the mourning family, overcharging them by thousands of dollars and issuing receipts for only half this amount-all while extolling the virtues of a moral Brahmin lifestyle! The family, though well aware of the priest's unethical behaviour, was too afraid to antagonise him because they believed that only he possessed sufficient skills to conduct the ceremony properly. Thus, they continued employing his services. The lesson learnt is that morality is not a prerequisite to being 1 st class.

Simultaneously, these actors are seen as distinguishable social types to be avoided. One respondent said:

I respect the good Brahmins, the 1st class ones, but I don't want to be like them. No way. They are weird. In fact, none of my Brahmin friends are so pure, if they were I guess we wouldn't be friends because our lifestyles would be too different.

In this vein, another observed:

I can't be 1 st class for two reasons. I eat meat and I'm not going to give that up. Also, even if I could I wouldn't want to be like them. You can't have a proper social life can you if you are so religious and always have to maintain your image? Being and class is fine with me.

Exclusion as a result of following the scripts associated with being 1 st class is a negative sanction which prevents actors in this category from being fully accepted by the rest. Combined, positive (public pressure) 
and negative (exclusion) sanctions act to keep 1 st class individuals in their role. Similar reasoning, applied in reverse, also keeps $4^{\text {th }}$ class individuals in theirs.

Those judged 2nd and $3^{\text {rd }}$ class are simultaneously accepted and marginalised because their statuses are transitional between Brahmin (1st class) and Non Brahmin (4th class) archetypes. Their deviances are seen as 'tolerable differences' that are accorded legitimacy, 'though perhaps grudgingly so' (Stebbins 1988: 3). Specific patterns of accommodation develop between these violators and enforcers. For violators this involves 'not flaunting their violations, exercising self regulation in time and place of offence [and] not embarrassing enforcers' (Wilson 1990: 594). For enforcers it involves masking their presence or avoiding the 'scene of the crime' altogether (Wilson 1990, p. 594). Meat eating is a good example of accommodation. Many insiders do it, but almost never at home or, if they are members, at SDBBS functions. Further, even when noticed it is rarely discussed, in the hope that it will go away.

Although social controls influence individuals, it is erroneous to think of people as passive actors who are located in a social structure, socialised, and controlled. Individuals can decide 'to shape their roles, say no to their socialisers, to go in directions never intended by authorities' (Charon 1999:146-7). In response to social controls, actors can choose one of three options-loyalty, exit, or voice (adapted from Hirschmann 1970). Exhibiting loyalty, actors choose to reduce or forgo norm violations although they may not want to. For example, loyalty is in play when an individual accedes to parental pressure by breaking off a relationship with a Chinese girlfriend. In contrast, choosing to engage in or continue with norm violations in spite of social controls reflects exit or voice. Exit describes actors who forsake caste identity by severing contact with their family and friends. Emigration as a response to parents' disapproval of mixed marriages exemplifies this.

Voice is the attempt to change, rather than exit, from an objectionable state of affairs (Hirschmann 1970: 30). Actors exhibiting voice are defiant; they remain in contact with Indians and continue to publicly pursue their norm violations. Three kinds of voice may be distinguished: primary, secondary, and tertiary. Actors employing primary voice commit norm violations and see their actions as deviations which they cannot stop. In secondary voice, deviant behaviour is employed as a means of 'defence, attack or adjustment to the overt and covert problems created by the consequent societal 
reaction' (Lemert 1951: 76). Here, the actor internalises his role as a deviant and commits norm violations partly because these violations are necessary for him to maintain his deviant identity. Tertiary voice goes further; the actor internalises the role and claims its legitimacy with respect to 'normal' roles. He no longer views his actions as deviant. The distinction between secondary and tertiary voice is subtle. In the former, the person committing the violation thinks of it as deviant and maintains it in opposition to the norm. In the latter, the violation is considered a norm in its own right.

James' conversion to Christianity illustrates each type of voice. Initially, he was uncertain and somewhat apprehensive about reading Christian scripture and attending Church. He did so only sporadically and covertly; his family and friends remained unaware of his interest. His confusion and fear of the stigma associated with conversion reflects primary voice. Societal reaction, when his conversion was made public many years later, was severe, with most of his family and friends questioning or condemning his decision. In response, he verbally attacked them by saying they would go to hell because they were not Christians. James had internalised his deviant role and was exhibiting secondary voice. Some time later, at a relative's funeral, James quietly but firmly refused to participate in the Brahmin rituals. This is an example of tertiary voice; no longer believing that he needed to defend his decision to convert by attacking Brahmin norms, he simply asserted his right to choose his faith.

\section{Is there a Singaporean Brahmin Community?}

Yes. The persistence of Brahmin identity, despite the contestations and renegotiations within it, and the presence of social controls provide tangible evidence of this. Additional proof comes from a day long seminar entitled 'Am I a Brahmin?'. This seminar functioned as a forum to gather and disseminate information and feedback. It aimed to 'tackle some hard questions that are on the minds of young Brahmins in Singapore' and exhorted participants to:

Remember that to live in a world of globalisation and a world that's going to be borderless, an awareness about who we are and where we come from can give us a quiet confidence to face life's many challenges. Many events in life and even daily demands require you to make choices and decisions. An awareness about your own identity can guide you to find answers to the many puzzling questions which are bound to confront you. 
The programme included a session where the final survey results were made public, 'Swamiji's' (a holy man believed by some to be an expert on Brahmin identity) discourse on Brahminism, and a discussion panel addressing the relevance of SDBBS and the practicalities of being Brahmin. Ample opportunities were created for the 120 participants to interact, question the speakers, disagree with them, and reflect on issues raised. Many were appreciative that identity concerns were engaged explicitly and in depth; $80 \%$ of the $5^{8}$ feedback forms returned (120 were distributed) stated that the seminar was useful in 'understanding Brahminism and its relevance in today's context'. One participant said:

I thought it was excellent. For once we are bringing things out into the open. If we talk about it then maybe we can find some solutions. Even if we don't, at least we tried. These problems are not going to disappear simply by ignoring them.

Others, however, felt the entire exercise was a waste of time; less than $5^{\circ}$ participants remained until the end. 'I came here because of parental pressure and some interest, but this Swamiji is too old, too boring, and from India. What does he know about Brahmins in Singapore?', said one. 'The idea was good but I learnt nothing from what was said. Seems like a brainwashing session. The seminar didn't really discuss our concerns or make changes. It only pretended to', said another. This façade was also apparent to some youth members of the organising committee who felt their role was confined only to grunt work and publicity. 'Let's organise it in such a way that we never ever have to do it again', was their shared sentiment. Also, even though the seminar's central premise was that determining Brahmin identity is difficult, SDBBS paradoxically restricted attendance 'only to Brahmins'. Non SDDBS members were welcome 'as long they are Brahmins'!

Despite a lack of concrete outcomes, the process was inherently beneficial to some. 'We didn't find any answers today, but we threw up a lot of important questions and issues. Hopefully that makes us think more', said one participant. 'Something needs to be done. Obviously we all disagree on even the most basic things. How can we all call ourselves Brahmin then?', said another. Retarding the efficacy of the seminar, however, were those caught in between, 'our parents' generation who must fear both the traditions of their parents and the excesses of their children. And rail against the one while reining in the other'. Ironically, it is this generation that is most concerned with ensuring the continuity of Brahmins. 
Participants at the seminar (at least some), and those whose testimonies were presented in section five, see that Brahmin identity is not definite or static. They recognise (sometimes) that it is contested, renegotiated, and riddled with dichotomies such as North Indian/South Indian, local/expatriate, youth/adult, and Tamil speaking/Hindi speaking. But this does not prevent them from believing that a Singaporean Brahmin community exists. This belief is not based on 'geographic or sociographic assertions of fact' (Cohen 1985: 98). Like other ethnic groups, the presence of a Singaporean Brahmin community arises:

Not... because of the degree of measurable or observable differences from other groups.... on the contrary, because the people in and the people out of it know that it is one; because both the ins and outs talk, feel, and act as if it were a separate group (Hughes 1984: 153-4, emphasis in original).

Indians' speech and actions illustrate the strength of their conviction. 'Youth are the pillars of tomorrow's Brahmin community. You will decide if we continue to flourish or start to decline', said one participant at the seminar. 'At the end of the day whatever our differences we share a common heritage', said another. 'Caste today is not the same as before, but we are still Brahmins, we must never forget that', remarked a third. For the grand finale of SDBBS' year-long 8oth anniversary celebrations, the President of Singapore, who is Indian, was invited as the guest of honour. An irate member wrote him a coarse letter filled with personal insults, warning him not to attend the function because he was not Brahmin. The letter itself is less significant than the reaction it got from SDBBS members. Individuals who had never bothered with Brahmin identity and those who openly disliked SDBBS were united in their hatred for the letter writer. His letter became a clarion for loyalty, with many saying that he had 'shamed the community'. A few non SDBBS members (comprising insiders and outsiders) who got to know of this incident also expressed similar reactions. Dissenters, who felt he had every right to write what he pleased, were ruthlessly silenced with arguments, insults, and hints that such thoughts represented ethnic treason. SDDBS, however, had no role in this silencing. The issue was never even publicly mentioned by the association. Understandably, committee members did not want to attract attention to it. To our knowledge no action was taken against the letter writer either. Clearly, Indians talk, feel, and act as if a Singaporean Brahmin community exists. Therefore it does. This imagined bond (Anderson 1983) originates from selective amnesia and collective ambivalence. 
Selective amnesia is a convenient cognitive and rhetorical strategy that trivialises disunity and emphasises, or creates, unity. In stark contrast to their daily experiences and actions, most Indians maintain that Brahmin identity is immutable. This deeply embedded axiom leads to the 'simple answer' discussed earlier. It is so unshakeable that even those who accept 'complex answers', or the general notion that Brahmin identity is problematic, relapse frequently or regress entirely. 'I thought about what you said for a while, but not anymore' and 'I can't really remember what was said at the seminar' are two responses in this vein. Another respondent said:

Your model is probably right. It ties in with my experience. But even if I understand it while I am sitting here discussing it with you, remembering or applying it while I am going about my daily life is impossible. It's easier to think that there are Brahmins and Non Brahmins, and these identities always stay the same. Black and white is much easier to deal with than grey.

Another type of selective amnesia involves 'situational' forgetting. For example, when talking about Brahmins to non Indians, or when discussing Brahmins in relation to other castes, insiders and outsiders usually omit or gloss over the differences that render Brahmin identity uncertain. Unlike the embedded axiom that leads to a real or deliberate memory loss, this action intentionally simplifies Brahmin identity in situations where details are unnecessary or too intricate to explain. This tendency is characteristic of most ethnic identities. If, for example, a Chinese asked us our race, we would reply that we were Indian. But if a North Indian asked us the same question, we might say we were Dravidian. Such situational shifting leads to a sense of 'us versus them'. In this case, it confers a weak consistency and unity to the categories of Brahmin and Non Brahmin.

Recasting Brahmins as Brahmanas is a third way in which selective amnesia operates. This primordial imperative obscures differences within and between Brahmin jatis and simultaneously legitimises all Brahmins as members of the Brahmana varna. It is a glocalisation strategy; one that links local forms to global forms (jati to varna) and global forms to local forms (Brahmana to Singapore Brahmin) (Sekar 2001). Differences amongst Brahmins are not simply forgotten. Instead, the effects of these differences are deemed negligible. 'Some of us eat meat, some don't. We believe in different religions. Our rituals, marriages, and most everything is different', acknowledged one respondent. 'In Bengal, Brahmins eat fish. In Goa, Christian Brahmins advertise for marriage alliances with other Christian 
Brahmins', said another. But, 'this is unimportant. What matters is we follow scriptures which are eternal truths and beyond religion. We are Brahmanas. That is the link between all Brahmins', is the belief espoused by many.

Even at the seminar such recasting, from Brahmin to Brahmana, was evident. 'There is no such thing as Brahminism or Brahmins, only Brahmanas. A Brahmana is one who has realised God', proclaimed Swamiji. By this definition, Brahmin is a meaningless identity, no one present was a Brahmana, and few aspired to it anyway. Yet, some participants' and organisers' interpretations of this were self serving. 'Swamiji is right, actually we are not Brahmins, that is a jati distinction which has many subdivisions. Like he said, we are actually Brahmanas; here there is only one category', said one. 'I hope now the youth realise they should not simply give up their caste identity and practices because as Swamiji clearly showed we have a long and detailed history', said another.

Some scholars signal the irrelevance of varna to caste communities today. 'It is unclear how far this notion of varna can survive as an ideological construct if its only empirical manifestation, i.e. jati, is progressively emptied of any reference to economic function and is regarded.... more in terms of some kind of cultural grouping', says Sharma (Sharma 1999: 36). Going further, Beteille suggests that in India caste is thought of more as jati than varna (Beteille 1996: 170). For Indians in Singapore, however, varna is vital to their belief in a Singaporean Brahmin community. It is a means by which the homogeneity of this identity is reasserted and justified when challenged from other grounds.

Collective ambivalence deters Indians from critically reflecting on Brahmin identity in private or public. One reason is that some perceive caste as a relic from India that has no place in Singapore society. Another is that caste is not usually relevant in everyday life, especially in interactions with non Indians who comprise $92 \%$ of the population. The political climate pre-empts agitation by caste based interest groups as well; the government would swiftly silence them. Reinforcing this, SDBBS is registered as a religious organisation, not a caste association. Beteille also observes that, to some extent, occupational obligations displace caste obligations (Beteille 1996: 174). In this vein, one speaker at the seminar noted:

The reality is that for most of us it is not possible to be full time Brahmanas. We can only be part timers. We must aim to be Brahmanas but at times we 
may have to be Shudras if necessary. For example, being an engineer is a Shudra's job, so we need to be Brahmana-Shudras, or Brahmana-Vaishyas if we are engaged in business.

Collective ambivalence is also fostered by a guilt complex that prevents insiders from thinking about or expressing Brahmin identity. 'There is a collective guilt which Brahmins share; a particular shame associated with being Brahmin', said one respondent. 'I know of a case where the boy's sacred thread ceremony was conducted quietly because he didn't want anyone [any Indians] to know he was Brahmin', said another. Frequently, Brahmins are vilified or parodied, especially by the media in South India. The attention given to the plight of Untouchables in academic and popular works has also meant that Brahmins are often portrayed as insular antagonists. An example of this is a text entitled Who is a Shudra? (Anand 200o). 'Selfish and hypocritical priests', 'inherent barbarian characteristics of Brahmins', and 'Brahmin parents teach the child how to treat and hate badly those Shudras' (Anand 2000: 48, 54, 63) are representative of the emotive examples found on every page. One respondent said:

Brahmins are not very well liked. Just switch on the [India cable] TV or surf the Internet and you will see how much anti Brahmin sentiment there is. Many people hate us. I think they probably have a right to feel that way. Some of the things done in the name of caste were atrocious. Nowadays we cannot expect to say we are Brahmins and automatically gain respect. It has to be earned.

\section{Another remarked:}

It's not that we are ashamed of being Brahmins because many of the portrayals are exaggerations and in any case we are not responsible for things done by our forefathers. But it is easier to minimise or conceal your Brahmin identity from other jatis. I am the subject of many jokes, especially when I eat meat or because of my accent. Also, although most of it is harmless, some people truly resent us because they think we think we are superior to them.

Unlike the case in India, there is no 'Anti-Brahmin' movement in Singapore. While some Anti-Brahmin sentiment was apparent in the 1970 s (the heyday of the Dravidian movement in India), the dichotomies emphasised by Indians in Singapore have always been organised along racial (North Indian/South Indian) and linguistic lines (Tamil speaking/Hindi speaking), not caste (Sinha 1993: 839-40; Rai 2004). So, the guilt complex is mainly a private, self-imposed state. It is not incited by any identifiable person or group in Singapore. 
'They must be religious and vegetarian and so on. So maybe some of them are afraid to be called Brahmins because they know they cannot meet these expectations', is yet another reason for collective ambivalence. Combined, the disdain for caste felt by some, the irrelevance of caste to interactions with non Indians, the political climate, occupational obligations, a guilt complex, and a fear of falling short of expectations mean Brahmin identity is rarely critically reflected upon in private and public. This leads to Indians ignoring the contestations and renegotiations of Brahmin identity, and unquestioningly accepting the presence of a Singaporean Brahmin community.

The paradox is that Indians subscribe to the idea of a Singaporean Brahmin community despite disunited realities and shifting individual identities. Selective amnesia and collective ambivalence show how this happens. Dissonance theory explains why selective amnesia and collective ambivalence operate. This theory states that dissonance results when a choice must be made between contrary cognitions (Festinger 1957). Discord can be resolved by favouring either cognition. For example, given two cognitions: (1) Brahmin identity is always in flux and (2) caste identity is immutable: most Indians will resist new learning and discard the former because they have been conditioned to accept the latter. This is why the 'simple answer' is preferred even by those who experience and agree with 'complex answers'.

Discord can also be resolved by altering or compromising between cognitions. Given another set: (1) a homogeneous Singaporean Brahmin community exists and (2) heterogeneous realities do not permit a Singaporean Brahmin community to exist: most Indians will synthesise these statements and arrive at, 'a heterogeneous Singaporean Brahmin community exists'. This reasoning is flawed because nothing unites all Brahmins in Singapore except the conviction amongst Indians that such a community is real. So, while heterogeneity exists, empirically (in terms of measurable or observable differences) a Singaporean Brahmin community should not. But it does; in individuals' minds. Dissonance theory shows 'how strong our desire is for reduction of uncertainty even via false premises' (Flohr 1986, p. 194). The Singaporean Brahmin community is, therefore, imagined as a defensive or coping reaction to the contestations and renegotiations that render Brahmin identity uncertain. Being imagined does not, however, make it fictive; it is as real as any other community. 


\section{Conclusion}

The question, 'Who is a Brahmin in Singapore?', has multiple answers because Brahmin identity is shaped by ever changing personal and social contexts. The cognitive model shows how Indians think about this identity (via number and severity of norm violations), and what names (Brahmin and Non Brahmin) and statuses (1st class to $4^{\text {th }}$ class) they assign, but not the actual outcome of one person judging himself or someone else (though we can make educated guesses). It tells us that in Singapore, a Brahmin is only a Brahmin, to some of the people, some of the time. The answer to the second question, 'Is there a Singaporean Brahmin community?', is an unequivocal yes. Selective amnesia and collective ambivalence create a unified (but imagined) super stratum that allows this community to establish and preserve itself despite significant uncertainty in determining individual identities. So, a Singaporean Brahmin community exists simply and only because most Indians are convinced it does.

The first answer is valuable because it shows that caste identity can be contested and renegotiated between individuals. This disproves the assumption that groups inevitably hold single or hegemonic opinions, and illustrates how fluid diasporic caste identities can be. The second answer is valuable because it shows that although individuals' caste identities are continually disputed and reconstructed, belief in the existence of a stable caste community persists. We suggest that this belief is one reason why caste remains salient to Indians in the diaspora; why routes do not become extinct in the face of a myriad of historical, political, and cultural influences. Overall, this study also illustrates how understanding community can be premised on understanding individuals; how sociology begins with psychology.

Following others, future research into Brahmins in Singapore can take a more overtly psychological approach. Freeman, for instance, investigates the salience of caste and other social identities in Sri Lanka through a questionnaire, which he analyses with significant statistical rigour (Freeman 2001). Using a scenario based instrument in India, and with questions similar to those in our final survey, Mahalingam details Brahmins' and Harijans' perceptions of caste origins and transformations (Mahalingam 1998). Alternatively, a traditionally sociological approach interrogating agents, institutions, and power relations would provide a better understanding of the conditions under which caste identities become unstable; as would a historical account documenting the arrival of Indians in Singapore. 
These approaches can also be applied to research on other diasporic caste communities. A comparative paper contrasting individuals' or communities' cognitive narratives is especially welcome as it would foster greater theoretical sophistication.

Such studies can be located within the burgeoning diaspora literatures. For example, diasporic 'imaginations' of India (Sarwar 2003), Indian identity (Singh 1997), Hindu identity (Sekar 2001), and South Asian American (Mani 2002) identity have all been analysed in depth. Or, such studies can be located within the field of ethnicity. Amongst Armenian-Americans, for instance, Bakalian finds that they do not regularly engage in 'Armenian' practices, but still retain a strong sense of Armenian heritage (Bakalian 1993). Thus, like Brahmins in Singapore, ethnic distinctiveness endures even in the absence or decline of culturally distinct practices (Cornell and Hartmann 1998). As shown, residing in Singapore is not enough to be a Singaporean Brahmin; neither is residing elsewhere sufficient cause not to be one. Further, what of online caste communities which share only cyberspace? These links, between caste identity, landscapes, and technoscapes (Appadurai 1996) also require exploration.

Homes are symbolic spaces grounded in personal and social meanings; in contrast, houses are physical spaces defined by material structures (Papastergiadis 1998, pp. 2-3). The ideal of the home is never circumscribed by the realities of the house; it is indifferent to rational arguments and impervious to external criticism (Papastergiadis 1998, p. 2). Home is the Singaporean Brahmin community which exists despite the contestations and renegotiations plaguing the house that is Brahmin identity in Singapore.

\section{Bibliography}

Ahmad, I (ed.). 1978. Caste and Social Stratification among Muslims in India. New Delhi: Manohar Publications.

Ali, S.F. 2001. 'Re-membering Selves: From Nobility and Caste to Ethnicity and Class in an Indian City', Unpublished PhD Dissertation. Virginia: Department of Sociology, University of Virginia.

Ali, S. 2002. 'Collective and Elective Ethnicity: Caste among Urban Muslims in India', Sociological Forum, Vol. 17, No. 4, pp. 593-620.

Anand, D.S. 20oo. Who is a Shudra. New Delhi: Blumoon Books.

Anderson, B. 1983. Imagined Communities: Reflections on the Origin and Spread of Nationalism. London: Verso.

Appadurai, A. 1996. Modernity at Large: Cultural Dimensions of Globalization. Minneapolis, Minnesota: University of Minnesota Press.

Bakalian, A. 1993. Armenian-Americans: From Being to Feeling Armenian. New Brunswick, NJ: Transaction. 
Barnett, S.A. 1975. 'Approaches to Changes in Caste Ideology in South India' in B. Stein (ed.). Essays on South India. Hawaii: University Press of Hawaii.

Barth, F. 1970a. 'Introduction' in F. Barth (ed.). Ethnic Groups and Boundaries: The Social Organization of Culture Difference. Oslo: Universitetsforlaget.

Barth, F. 197ob. 'Pathan Identity and its Maintenance' in F. Barth (ed.). Ethnic Groups and Boundaries: The Social Organization of Culture Difference. Oslo: Universitetsforlaget.

Beteille, A. 1996. 'Caste in Contemporary India' in C.J. Fuller (ed.). Caste Today. Delhi: Oxford University Press.

Charon, J. 1999. The Meaning of Sociology. 6th ed. New Jersey: Prentice-Hall.

Cohen, A.P. 1985. The Symbolic Construction of Community. London: Tavistock.

Cohn, B. 1987. An Anthropologist among the Historians and Other Essays. Delhi: Oxford University Press.

Cornell, S. and Hartmann, D. 1998. Ethnicity and Race. Thousand Oaks, CA: Pine Forge Press.

Das, V. 1987. Structure and Cognition: Aspects of Hindu Caste and Ritual. Delhi: Oxford University Press.

Denzin, N.K. 1989. Interpretive Interactionism. Newbury Park, CA: Sage.

Dhalla, P.E.H. 2ooo. 'Defining Difference, Defining Moments: Competing Moral Discourses, Constitutional Options, and "Indian" Ethnic Identities During the Transition from Apartheid to Democracy in South Africa, 1990-1994', Unpublished PhD Dissertation. Cambridge, MA: Department of Anthropology, Harvard University.

Dirks, N.B. 2001. Castes of Mind: Colonialism and the Making of Modern India. Princeton, NJ: Princeton University Press.

Dumont, L. 1970. Homo Hierarchicus: An Essay on the Caste System. Chicago: University of Chicago Press.

Evers, H. and Pavadarayan, J. 1993. 'Religious Fervour and Economic Success: The Chettiars of Singapore' in K.S. Sandhu and A. Mani (eds.). Indian Communities in Southeast Asia. Singapore: Institute of Southeast Asian Studies.

Festinger, L. 1957. A Theory of Cognitive Dissonance. Stanford, CA: Stanford University Press.

Flohr, H. 1986. 'Biological Bases of Social Prejudice' in V. Reynolds, V. Falger, and I. Vine (eds.). The Sociobiology of Ethnocentrism: Evolutionary Dimensions of Xenophobia, Discrimination, Racism, and Nationalism. Athens: University of Georgia Press.

Fox, R.G. 1969. 'Varna Schemes and Ideological Integration in Indian Society', Comparative Studies in Society and History, Vol. 1 1, No. 1, pp. 27-45.

Freeman, M. 2001. 'Linking Self and Social Structure: A Psychological Perspective on Social Identity in Sri Lanka', Journal of Cross-Cultural Psychology, Vol. 32, No. 3, pp. 291-308.

Govindasamy, D. 1975. 'Social Change and the Caste System: Intergenerational Attitudes towards Caste Practices of the Brahmin Community in Singapore', Unpublished Honours Dissertation. Singapore: Department of Sociology, National University of Singapore.

Gould, H. 1987. The Hindu Caste System. Delhi: Chanakya Publications.

Guneratne, A. 1998. 'Modernization, the State, and the Construction of a Tharu Identity in Nepal', Journal of Asian Studies, Vol. 57, No. 3, pp. 749-773.

Heckert, D.M. 2003. 'Positive Deviance' in P. Adler and P.A. Adler (eds.). Constructions of Deviance: Social Power, Context, and Interaction. $4^{\text {th }}$ ed. Victoria: Thomson Wadsworth.

Hirschman, A.O. 1970. Exit, Voice, and Loyalty: Responses to Decline in Firms, Organizations, and States. Cambridge, MA: Harvard University Press.

Hollup, O. 1994. 'The Disintegration of Caste and Changing Concepts of Indian Ethnic Identity in Mauritius', Ethnology, Vol. 33, No. 4, pp. 297-316. 
Howe, L. 1995. Status Mobility in Contemporary Bali: Continuities and Change. Hull: Centre for Southeast Asian Studies, University of Hull.

Hughes, E.C. 1984. The Sociological Eye: Selected Papers. New Brunswick, NJ: Transaction Books.

Inden, R. 1986. 'Orientalist Constructions of India', Modern Asian Studies, Vol. 20, No. 3, pp. 401-446.

Inden, R. 1990. Imagining India. Cambridge, MA: Basil Blackwell.

Kaur, R. 1986. 'Jat Sikhs: A Question of Identity', Contributions to Indian Sociology, Vol. 20, No. 2, pp. 221-239.

Lemert, E.M. 1951. Social Pathology. New York: McGraaw-Hill.

Lynch, O.M. 1996. 'Contesting and Contested Identities: Mathura's Chaubes' in W. Dissanayake (ed.). Narratives of Agency: Self-Making in China, India, and Japan. Minneapolis: University of Minnesota Press.

Mahalingam, R. 1998. 'Essentialism, Power, and Representation of Caste: A Developmental Study', Unpublished PhD Dissertation. Pittsburgh: Department of Arts and Sciences, University of Pittsburgh.

Mani, B. 2002. 'The Imagination of South Asian America: Cultural Politics in the Making of Diaspora', Unpublished PhD Dissertation. Stanford, CA: Department of Modern Thought and Literature, Stanford University.

Mitra, S.K. 1994. 'Caste, Democracy, and the Politics of Community Formation in India' in M. Searle-Chatterjee and U. Sharma (eds.). Contextualising Caste: PostDumontian Approaches. Oxford: Blackwell.

Nagel, J. 1994. 'Constructing Ethnicity: Creating and Recreating Ethnic Identity and Culture', Social Problems, Vol. 41, No. 1, pp. 152-176.

Nagel, J. 1995. 'American Indian Ethnic Renewal: Politics and the Resurgence of Identity', American Sociological Review, Vol. 6o, No. 6, pp. 947-966.

Papastergiadis, N. 1998. Dialogues in the Diasporas: Essays and Conversations on Cultural Identity. London: Rivers Oram Press.

Parish, S.M. 1996. Hierarchy and its Discontents: Culture and the Politics of Consciousness in Caste Society. Philadelphia: University of Pennsylvania Press.

Parkin, R. 200o. 'Proving "Indigenity", Exploiting Modernity: Modalities of Identity Construction in Middle India', Anthropes, Vol. 95, No. 1, pp. 49-63.

Parry, J.P. 1979. Caste and Kinship in Kangra. London: Routledge and Kegan-Paul.

Pathak, A.A. 1998. 'To Be Indian (Hyphen) American: Communicating Diaspora, Identity, and Home', Unpublished PhD Dissertation. Norman, Oklahoma: Department of Communication, University of Oklahoma.

Quigley, D. 1993. the Interpretation of Caste. Oxford: Clarendon Press.

Quigley, D. 1994. 'Is a Theory of Caste still Possible?' in M. Searle-Chatterjee and U. Sharma (eds.). Contextualising Caste: Post-Dumontian Approaches. Oxford: Blackwell.

Rai, R. 2004. "Race" and the Construction of the North-South Divide amongst Indians in Colonial Malaya and Singapore', South Asia, Vol. 27, No. 2, pp. 245-264.

Sarwar, S. 2003. 'Selective Memory: Diaspora Writing in Rohinton Mistry's Fiction', Unpublished MA Dissertation. Calgary, Alberta: Department of English, University of Calgary.

Searle-Chatterjee, M. and Sharma, U. 1994. 'Introduction' in M. Searle-Chatterjee and U. Sharma (eds.). Contextualising Caste: Post-Dumontian Approaches. Oxford: Blackwell.

Sekar, R. 2001. 'Global Reconstruction of Hinduism: A Case Study of Sri Lankan Tamils in Canada', Unpublished PhD Dissertation. Ottawa: University of Ottawa.

Sheth, D.L. 200o. 'Caste and the Secularisation Process in India' in P. R. deSouza (ed.). Contemporary India-Transitions. New Delhi: Sage.

Sharma, U. 1999. Caste. Buckingham: Open University Press. 
Shyamlal. 1992. 'De-Sanskritisation and High Caste Converts into "Bhangis"', The Indian Journal of Social Work, Vol. 53, No. 2, pp. 273-283.

Shyamlal. 1995. 'Acquiring a Dalit Identity: Downward Mobility of Some Upper Castes of Rajasthan', Sociological Bulletin, Vol. 44, No. 1, pp. 86-88.

Shyamlal. 1996. 'Conversion of Upper Castes into Lower Castes: A Process of Asprashyeekaran (Encompassing Untouchability)', The Indian Journal of Social Work, Vol. 57, No. 2, pp. $163^{-1} 78$.

Shyamlal. 1997. From Higher Caste to Lower Caste: The Process of Asprashyeekaran and the Myth of Sanskritization. Jaipur: Rawat Publications.

Singapore Department of Statistics. 2005. Monthly Digest of Statistics, Feb 2005. Singapore: Singapore Department of Statistics.

Singh, S. 1997. 'The Social Construction of a Collective 'Indian' Ethno-Religious Identity in a Context of Ethnic Diversity: A Case Study of an Indo-Caribbean Hindu Temple in Toronto', Unpublished PhD Dissertation. Toronoto: Department of Sociology, University of Toronto.

Singh, V.P. 1992. Caste Community and Conflict in Social Change. New Delhi: Commonwealth Publishers.

Sinha, V. 1993. 'Hinduism in Contemporary Singapore' in K.S. Sandhu and A. Mani (eds.). Indian Communities in Southeast Asia. Singapore: Institute of Southeast Asian Studies

Smaje, C. 200o. Natural Hierarchies: The Historical Sociology of Race and Caste. Malden, MA: Blackwell.

Srinivas, M.N. 1989. The Cohesive Role of Sanskritization and Other Essays. Delhi: Oxford University Press.

Stake, R.E. 1995. The Art of Case Study Research. Thousand Oaks, CA: Sage.

Stebbins, R.A. 1988. Deviance: Tolerable Differences. Toronto: McGraw-Hill Ryerson.

Sundar, N. 2000. 'Caste as Census Category: Implications for Sociology', Current Sociology, Vol. 48, No. 3, pp. 111-126.

Tharamangalam, J. 1996. 'Caste Among Christians in India' in M.N. Srinivas (ed.). Caste: Its Twentieth Century Avatar. New Delhi: Viking.

Turner, R.H. 1976. 'The Real Self: From Institution to Impulse', American Journal of Sociology, Vol. 81, No. 5, pp. 989-1016.

Unnithan, M. 1994. 'Girisias and the Politics of Difference in Rajasthan: "Caste", Kinship, and Gender in a Marginalised Society' in M. Searle-Chatterjee and U.Sharma (eds.). Contextualising Caste: Post-Dumontian Approaches. Oxford: Blackwell.

Velayutham, S. and Wise, A. 2005. 'Moral Economies of a Translocal Village: Obligation and Shame among South Indian Transnational Migrants', Global Networks, Vol. 5, No. 1, pp. 27-47.

Wilson, M. 1990. 'Folk Crime: Patterns of Accommodation' in C.D. Bryant (ed.). Deviant Behavior: Readings in the Sociology of Norm Violations. New York: Hemisphere Publishing.

Woodward, K. 2002. Understanding Identity. London: Arnold.

Yin, R.K. Applications of Case Study Research. (2nd ed.) Thousand Oaks, CA: Sage. 